\title{
Anika Liversage
}

\section{Tyrkiske skilsmisser i Danmark}

I Danmark ender ægteskaber langt oftere i skilsmisse, end ægteskaber i Tyrkiet gør. På baggrund af registerdataanalyser viser denne artikel, at skilsmisser blandt indvandrere og efterkommere fra Tyrkiet er blevet stadigt hyppigere gennem de sidste tre årtier, hvor niveauet er steget fra det lave tyrkiske til det højere danske niveau. Interviews med fraskilte tyrkiske mænd og kvinder i Danmark såvel som i Tyrkiet viser, at denne stigning blandt andet kan tilskrives ændrede magtforhold imellem kønnene. Her giver danske samfundsstrukturer som adgang til lønarbejde, uddannelse og sociale ydelser kvinderne bedre muligheder for at forlade dårlige ægteskaber, uanset at der ofte er modstand herimod i familier og netværk. Andre skilsmisser udspringer af generationelle konflikter over partnervalg og over, hvordan ægteskaber overhovedet bør etableres. Endelig har også mulighederne for, at familiesammenførte ægtefæller kan opnå egen opholdstilladelse, betydning i nogle skilsmisser. Her ses, at nogle herboende ægtefæller benytter sig af muligheden for simpelthen at skaffer sig af med uønskede partnere ved at få dem sendt tilbage til Tyrkiet. Samlet set dokumenterer artiklen, at migrationens voldsomme forandringer også slår igennem som spændinger over, hvad ægteskaber bør og ikke bør være, hvornår de kan opløses og af hvem.

Søgeord: Skilsmisse, tyrkiske indvandrere, migration, transnationale netværk, køn, generation. 
$\mathrm{I}$ de sidste fire årtier er befolkningen i Danmark blevet stadig mere mangfoldig, og det, som Danmarks Statistik afgrænser som "ikke-vestlige indvandrere og efterkommere", udgør i dag $7 \%$ af befolkningen (Social- og Integrationsministeriet 2012). I denne brede gruppe dokumenterer studier, at ægteskab ofte tillægges ganske stor betydning og ikke blot involverer de enkelte unge, men også deres bredere familier (Bredal 2006, Rytter 2006, Timmerman 2008). Når der lægges stor vægt på, hvem der indgår ægteskab med hvem og hvordan, skyldes det blandt andet, at ægteskabspraksisser har afgørende indflydelse på, hvem der bliver forældre til den næste generation og dermed, hvorvidt givne etniske grupper videreføres eller over tid gradvist opløses (Mooney 2006).

Det er dog ikke kun de måder, man indgår ægteskaber på, der præger en etnisk minoritetsgruppes familiepraksisser. Også opløsning af ægteskaber, altså skilsmisser, har stor betydning for, om familierne i en etnisk minoritetsgruppe kan anses for at være solide og stabile eller ej. Netop her bruger nogle etniske minoriteter den høje danske skilsmisserate som en markør, der adskiller minoriteterne fra majoritetsbefolkningen: "De" (dvs. "danskerne") fremhæves som nogle, der bliver skilt hyppigere og på et spinklere grundlag end "os" (dvs. "etniske minoriteter"), hvor familien fremstilles som mere holdbar (Singla 2006). Spørgsmålet er dog, om der er empirisk belæg for denne opfattelse og, i forlængelse heraf, hvad der kan føre til, at etniske minoritetspar bliver skilt. Modsat den betragtelige forskning om etniske minoriteters ægteskaber er den forskningsmæssige viden om skilsmisser blandt etniske minoriteter nemlig begrænset.

Denne artikel belyser derfor udviklingen i skilsmisser i én udvalgt etnisk minoritetsgruppe - personer med tyrkisk baggrund. Analysen trækker dels på registerdata, dels på interviews med fraskilte kvinder og mænd, hvis ægteskaber er blevet opløst igennem de sidste tre årtier. Artiklens formål er at undersøge, om udviklingen i skilsmisser i denne periode kan forstås som et migrantsamfunds gradvise og modsætningsfyldte bevægelse fra en "snæver", til en mere "bred" socialisation (Arnett 1995).

Når jeg har valgt at fokusere på én minoritetsgruppe, er det fordi "etniske minoriteter" er en meget sammensat gruppe med betragtelige forskelle mellem forskellige gruppers praksisser på familieområdet (se fx Jakobsen m.fl. 2006). Den tyrkiske gruppe er udvalgt, fordi det er den største etniske minoritetsgruppe i Danmark - der er i dag ca. 60.000 indvandrere og efterkommer fra Tyrkiet (Danmarks Statistik 2011). Ifølge et svensk studie fra 1999 ligger skilsmisseraten i denne gruppe endvidere lavere end niveauet i de fleste andre etniske minoritetsgrupper (Darvishpour 1999).

Undersøgelsen føjer sig til de - stadig ret få - eksisterende studier af skilsmisseprocesser i forskellige etniske minoritetsgrupper. Her kan fx nævnes Darvishpours svenske undersøgelse af skilsmisser blandt iranske indvandrerpar (Darvishpour 1999), Mehdis arbejde med islamiske regler og normers be- 


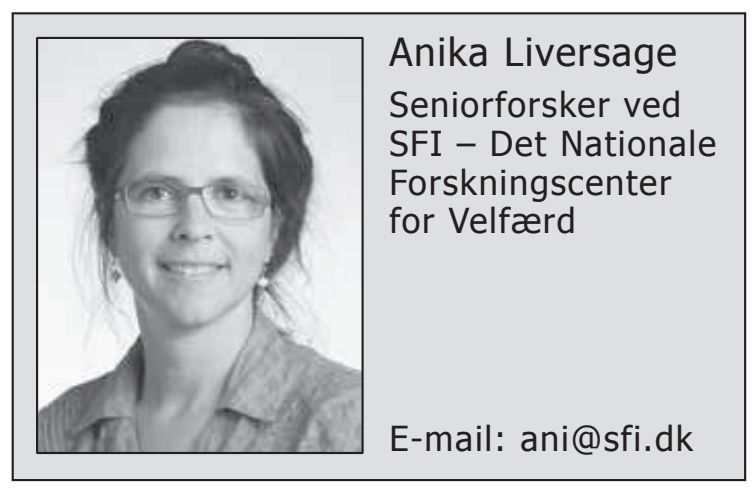

tydninger for pakistanske kvinders skilsmisser i Danmark (Mehdi 2007, Mehdi m.fl. 2008), Akpinars belysning af nogle tyrkiske kvinders problemer med at blive skilt i Sverige (Akpinar 2003) og Guru's diskussion fra England af, at skilsmisser for nogle indvandrede kvinder opleves som frisættende (Guru 2009). ${ }^{1}$

\section{Analysetilgang - Arnetts begreber om "bred" og "snæver" socialisation}

Skilsmisser er et komplekst fænomen, hvilket gør det svært at lave en snæver afgrænsning af de involverede processer. Jeg finder det derfor relevant ikke kun at se på de konkrete skilsmisser, men også på hvorfor visse typer af ægteskaber efterfølgende viser sig at have svært ved at holde. Derudover er det - med etniske minoritetsfamiliers engagement $i$ indgåelse af ægteskaber in mente - vigtigt ikke kun at se på de fraskiltes egne indstillinger til at bryde ægteskaber, men også på hvordan andre familiemedlemmer oplever og eventuelt påvirker skilsmisser. I en migrationskontekst er det endelig også vigtigt at se på, hvordan to forskellige kontekster - i dette tilfælde Tyrkiet og Danmark - spiller sammen over tid.

Sidstnævnte sammenligning er vigtig, fordi der er betragtelige forskelle imellem, hvordan man generelt "gør" familie i de to lande. Følger vi sociologen Göran Therborns opdeling af verden i fem større familiesystemer (Therborn 2005), tilhører Danmark den "kristne europæiske familie" i dens mest ligestillingsorienterede, skandinaviske variant. Tyrkiet derimod hører til en islamisk kulturkreds om end i en modificeret form grundet de europæiserings- og moderniseringstiltag, den tyrkiske republik indførte efter 1923. De store forskelle imellem Danmark og Tyrkiet fremgår $\mathrm{fx}$ af værdiundersøgelser som European Values Survey (Halman m.fl. 2012). Her ligger Danmark og Tyrkiet i hver sin ende af et værdimæssigt spektrum med hensyn til spørgsmål som, hvorvidt det er acceptabelt at bo sammen uden at være gift, eller om det kan accepteres, at enlige kvinder vælger at få børn alene. På begge disse spørgsmål svare mange danskere "ja", og mange tyrkere "nej". Med hensyn til acceptabiliteten af skilsmisse er der også klare forskelle: På en skala fra et ("skilsmisse kan aldrig retfærdiggøres") til ti ("skilsmisse kan altid retfærdiggøres"), ligger Tyrkiet på godt tre og Danmark på knap otte (2012:20). 
Det er disse to forskelligartede kontekster, der kommer i berøring via international migration, og i denne artikel argumenterer jeg for, at samspillet imellem dem har stor betydning for, hvordan skilsmisser blandt tyrkere i Danmark praktiseres og forandres over tid. Som teoretisk ramme for analysen anvender jeg Arnetts begreber om "bred" og "snæver" socialisation fra artiklen "Broad and narrow socialization: The family in the context of a cultural theory" (Arnett 1995). Dette gør jeg, dels fordi denne tilgang har en bredde, der er velegnet til indeværende analyse, og dels fordi forskellene i familieværdier indikerer, at Tyrkiet og Danmark er kendetegnet ved det, Arnett kalder henholdsvis en "smal" og en "bred" socialisation - forskelle der i høj grad har betydning, når det gælder ægteskab og skilsmisse.

Arnett definerer socialisation som "the process by which people acquire the behaviours and beliefs of the social world", dvs. såvel, hvordan man gifter sig og lever i et ægteskab, som hvordan livet i det hele taget "bør" leves (Arnett 1995:618). Denne socialisation foregår blandt andet i familien, hvor børn og unge præges under deres opvækst. Men familien er kun én kilde til individers socialisation. Herudover fremhæver Arnett seks andre kilder til socialisation. Disse kilder er venner, skole/arbejde, lokalsamfundet (org: "community"), medier, det juridiske system og - mere overordnet - dominerende kulturelle koder og normer (org: "cultural belief system") (Arnett 1995:617). I et givent samfund vil der ofte være en ganske høj grad af overensstemmelse imellem de forskellige kilder, således at det, individer socialiseres til i familien, bereder dem til livet i fx lokalsamfundet og i uddannelses- og arbejdslivet. Samtidig kan der dog også være forskelle, som fx når socialisation blandt venner præger til en anden adfærd end den konformitet, som fx familie og skole tilskynder til.

Arnett skelner endvidere imellem kulturer, som har henholdsvis en "snæver" og en "bred" socialisation. I en "snæver" kontekst socialiseres individer til en forholdsvis høj grad af lydighed og konformitet, og den enkelte forventes at følge bestemte - og forholdsvis fastlagte - spor i tilværelsen. "Bred" socialisation tilskynder derimod til individualisme og uafhængighed, og der er her større variation i de spor, den enkelte kan følge i tilværelsen. Tages ægteskab som eksempel, vil der i kulturer med en "snæver" socialisation tilskyndes til, at alle unge fx gifter sig i en ung alder. I kulturer med en "bred" socialisation vil der være langt større variation i alderen for ægteskabs indgåelse, ligesom nogle ikke vil gifte sig, men i stedet enten leve i andre former for forhold eller leve alene.

Forskellen på kulturer, der lægger vægt på henholdsvis "snæver" og "bred" socialisation, handler til dels om samfundenes grad af kompleksitet og økonomiske udvikling: I komplekse samfund giver det ikke god mening at anvise unge meget snævre spor, som de skal holde sig indenfor, fx i overgangen til at blive voksen (Arnett 2004). Samtidig kan nogle komplekse samfund dog godt lægge vægt på snæver socialisation, og Arnett (1995) fremhæver her 
Japan som et strukturel og økonomisk komplekst samfund, hvor der tilskyndes til lydighed og konformitet. Vender vi tilbage til sammenligningen imellem Danmark og Tyrkiet viser værdiundersøgelser, at børns lydighed over for deres forældre ikke tilskrives den store værdi i Danmark, mens det anses for overordentligt vigtigt i Tyrkiet (Halman m.fl. 2012:26-28).

Endelig observerer Arnett, at der for immigranter kan være ganske stor forskel på de former for socialisation, der er fremherskende, fx i familie og lokalsamfund (hvor etniske minoritetsnormer kan stå stærkt) og i andre domæner, som fx uddannelsessystemet/arbejdsmarkedet og det juridiske system, hvor det i stedet er majoritetens normer, der er fremherskende. Som han skriver:

Immigrant families frequently experience a conflict between the socialization practices that they bring with them to their new country and the socialization that they are exposed to in schools, the media, and the legal system (Arnett 1995:625).

Personer, der er indvandrede som voksne vil dermed møde andre normer og praksisser i modtagerlandets arbejdsliv, end det der dominerer i den kontekst, de kommer fra, og hvor de blev socialiserede i deres opvækst.

Endnu mere kompleks bliver situationen for unge, der er opvokset i Danmark i etniske minoritetsfamilier. Her kan forældre (ud fra deres egen socialisation i en anden kontekst) ønske at give deres afkom en "snæver" socialisation, fx med klare normer for, hvordan og hvornår man bør gifte sig, og at disse ægteskaber bør holde. De unge vil dog i skolen og blandt venner blive eksponeret for en langt "bredere" socialisation, hvor fokus i stedet ligger på, at man skal lære sig selv at kende, og udtrykke sin egen individualitet, frem for at følge en snæver, slagen sti. Dermed kan der opstå spændinger imellem generationerne - imellem en "første generation", der i høj grad er præget af oprindelseslandets normer, og en "anden generation" der er socialiseret i en mere modsætningsfyldt kontekst.

Når Arnetts begreber er relevante i forhold til denne undersøgelse, skyldes det, som nævnt, at ægteskab (og - som en naturlig følge heraf - også skilsmisse) i Tyrkiet anses for at være et kollektivt fremfor (kun) et individuelt projekt, og som der er klare - snævre - normer for. Ser man fx på processer omkring indgåelse af - eller afslutning af - parforhold i henholdsvis Danmark og Tyrkiet, er forskellene tydelige. I Danmark er ugift samboskab udbredt, og de, der vælger at blive gift, gør det normalt først, når en familie, efter fødslen af et første barn, de facto er blevet stiftet (Ottosen 2011). Således er en kvinde i gennemsnit 29 år, når hun får sit første barn, men 32 år når hun bliver gift første gang (Danmarks Statistik 2012). Uanset at par dermed ofte har kendt hinanden i årevis, inden de eventuelt vælger at gifte sig, ender omkring 40 \% af disse ægteskaber alligevel i skilsmisse (Olsen m.fl. 2005). Dette er i tråd med en generel opfattelse af, at det er bedre at opløse et ægteskab end at blive sammen for enhver pris (Tænketanken 2007). 
Til forskel herfra er giftealderen i Tyrkiet lavere (22 år i 2000, i Nauck m.fl. 2005:371), ugift samboskab er kun i ringe grad et alternativ til ægteskab (White 2004), og der lægges generelt stor vægt på, at kvinder er jomfruer, før de bliver gift (Cindoglu 1997, Ozyegin 2009). Forældre er endvidere ofte stærkt involverede i deres børns indgåelse af ægteskab (Delaney 1991, Hart 2007), og det sker ganske hyppigt, at unge, nygifte par flytter ind med brudgommens forældre i forholdets første år (Aykan \& Wolf 2002). I forlængelse af den store betydning, som giftemålet tillægges for folks livsbaner, forventes ægteskaber også at holde. Og på grund af den store vægt, der lægges på, at kvinder er jomfruer på bryllupsnatten, er der er et betragteligt stigma knyttet til skilsmisse, især for kvinder (Kavas 2010, Müftüler-bac 1999). Dette stigma kan ikke blot gå ud over de fraskilte selv, men også fx deres forældre, fordi en skilsmisse kan blive set som et tegn på, at forældre ikke har haft "styr på" deres børn - altså socialiseret dem til at følge den rette, snævre sti. Derfor kan nogle tyrkere, der ønsker at forlade et ægteskab, opleve, at deres familier forsøger at forhindre dette eventuelt ved at true med at slå hånden af dem eller endda ved at tage voldelige midler i brug (Akpinar 2003, DanneskioldSamsøe m.fl. 2011).

Et andet sted at iagttage en forskel imellem de to lande er i det juridiske system - et af de syv domæner for socialisation, som Arnett fremhæver. Når folk ønsker skilsmisse i Danmark, er der en liberal adgang hertil, og man behøver fx ikke at begrunde, hvorfor man ønsker et ægteskab opløst. Det er også muligt ensidigt at blive skilt, hvilket blot kræver en separationstid på tolv, i stedet for på seks, måneder. Modsat har Tyrkiet godt nok en sekulær familielovgivning, der er baseret på schweizisk forbillede, og bygger dermed ikke på muslimske principper, hvor en mand har lettere adgang til skilsmisse end en kvinde (Liversage \& Jensen 2011). Dog skulle en kvinde i Tyrkiet helt frem til $1990 \mathrm{fx}$ have sin mands tilladelse for at kunne tage arbejde uden for hjemmet (Örücü 2010:274). Endvidere skal anmodninger om skilsmisse (som bevilges af en domstol) begrundes, ligesom en skilsmisse i Tyrkiet ofte tager længere tid at få gennemført end i Danmark. Inden en revision af lovgivningen i 2002 kom kvinder derudover ofte til at stå meget svagt økonomisk, hvis et par blev skilt - en situation, der stadig kan forekomme til trods for den ændrede lovgivning (Örücü 2010).

\section{Undersøgelsens første metode - analyse af registerdata}

Et første formål med denne artikel er at fastslå, hvor ofte tyrkere i Danmark bliver skilt, og hvordan udviklingen i antallet af skilsmisser i denne gruppe har set ud de seneste årtier. Dette kan gøres ved hjælp af registerdata, da alle personer, der enten er født i Danmark eller har lovligt ophold her i mere end tre måneder, får tildelt et cpr-nummer. Figuren nedenfor viser således skilsmisser blandt personer med tyrkisk baggrund i Danmark fra 1981 til 2007.² Opgørelsen er afgrænset til endogame ægteskaber, hvor begge ægtefæller har 
haft tyrkisk baggrund. Denne form for ægteskaber er fremherskende blandt tyrkere i Danmark (Danmarks Statistik 2011:33-35).

I perioden fra 1981-2007 var der ca. 11.680 tyrkiske par i Danmark, der blev gift, og i den undersøgte periode gik ca. 2.460 par efterfølgende fra hinanden. ${ }^{3}$ Figur 1 viser opløsningsraten for disse ægteskaber over tid, fordelt på ægteskaber indgået i henholdsvis 1980'erne, i 1990'erne samt i starten af 2000'erne.

Figur 1: Opløsningsraten for tyrkiske ægteskaber indgået i

Danmark i perioden 1981 - 2003

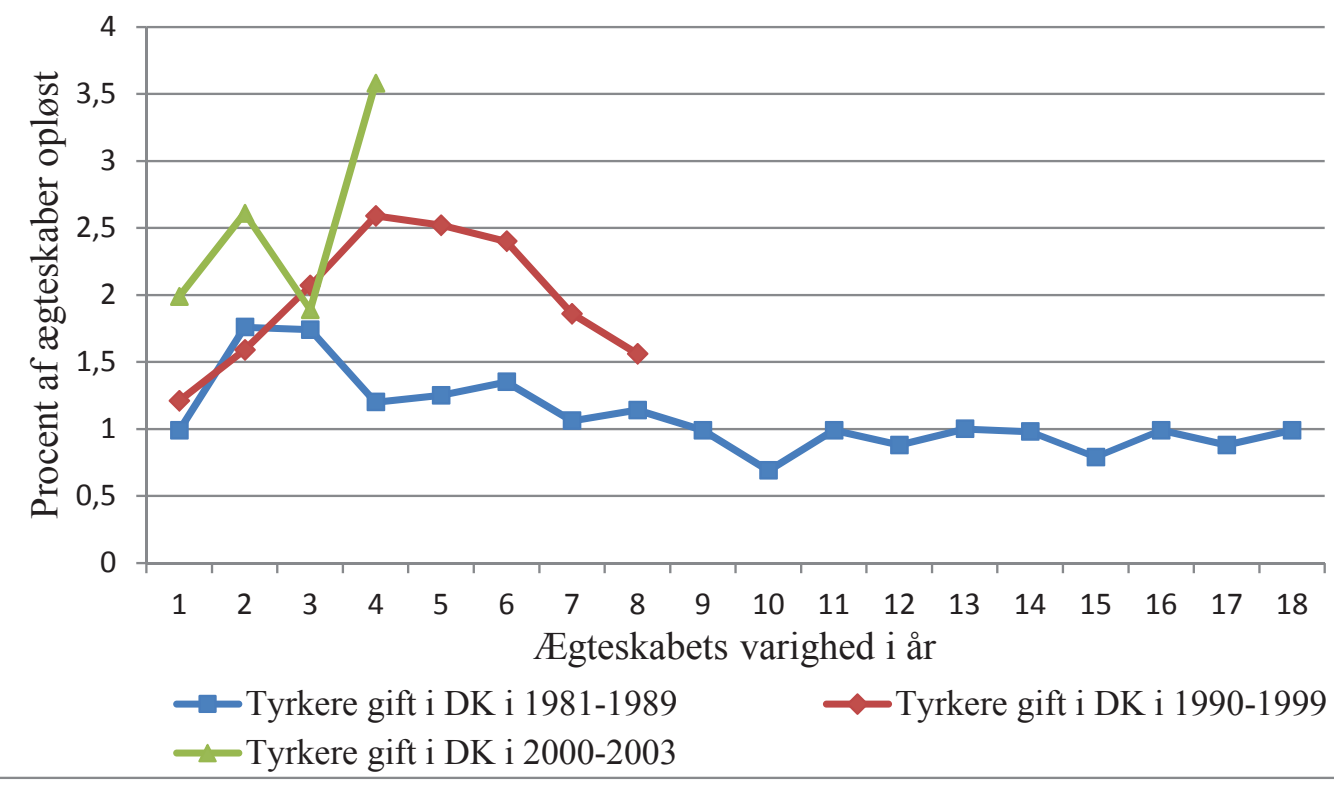

Figur 2: Opløsningsraten for alle ægteskaber i Danmark og i Tyrkiet

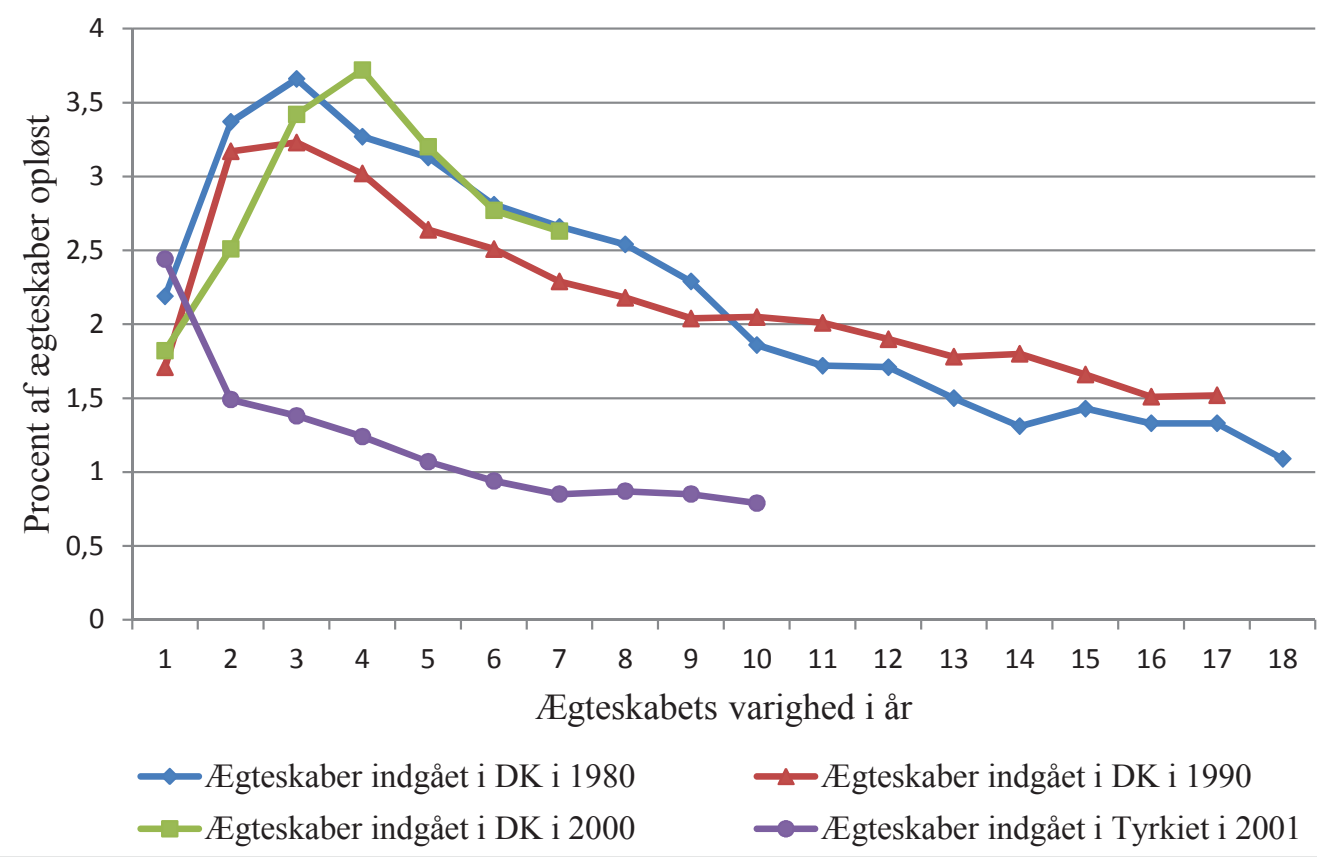


Ægteskaber indgået i 1980'erne kan følges over 18 år, hvorimod par, der er gift fra 2000 til 2003, som samlet gruppe kun kan følges i fire år.

Til sammenligning viser figur 2 opløsningsraten for danske ægteskaber indgået i henholdsvis 1980, 1990 og 2000. I denne periode har den danske skilsmisserate ikke undergået de store forandringer, men ligget på et - i international sammenhæng - konstant relativt højt niveau. Endelig viser figur 2 også den klart lavere opløsningsrate for ægteskaber indgået i Tyrkiet i 2001 (data hentet fra Danmarks Statistik, samt Tyrkiets Statistiske Institut).

Figur 1 viser tydeligt, at andelen af tyrkiske ægteskaber i Danmark, der opløses, stiger fra årti til årti. En sammenligning imellem figur 1 og figur 2 viser endvidere, at hvor tyrkiske skilsmisser i Danmark i 1980'erne lå på omtrent samme lave niveau, som findes i Tyrkiet i det nye årtusinde, tangerer skilsmisseniveauet for tyrkiske ægteskaber indgået i Danmark efter år 2000 det klart højere danske niveau. Dermed blev tyrkiske par, gift i perioden 20002003, skilt omtrent lige så hyppigt som majoritetsdanske par. Med andre ord dokumenterer disse registerdata, at der er sket en klar stigning i skilsmissehyppigheden blandt tyrkere i Danmark over en periode på tre årtier, hvor skilsmisseraten i gruppen har bevæget sig fra det lave tyrkiske til det højere danske niveau. Denne markante stigning i skilsmissefrekvensen rejser spørgsmålet om, hvilke sociale processer der kan ligge bag denne stigning. For at besvare dette spørgsmål vil jeg i det følgende trække på kvalitativ empiri.

\section{Undersøgelsens anden metode - livshistoriske interviews med fraskilte tyrkere}

Den kvalitative empiri består af 31 interviews med fraskilte tyrkere - 23 kvinder og 8 mænd, udført i 2009-2011. Disse interviews danner grundlag for en analyse, der ønsker at forstå stigningen i skilsmissefrekvensen over tid. Analysen tager afsæt i Arnetts begreber om "snæver" og "bred" socialisation, som blev præsenteret tidligere.

Netop fordi skilsmisse ofte anses for stigmatiserende blandt tyrkere, interviewede jeg fraskilte tyrkere for bedre at forstå, hvad der kunne ligge bag, når folk alligevel valgte at blive skilt. Som interviewform brugte jeg en livshistorisk tilgang (Liversage 2009a, Bertaux 2003, Siig Andersen \& Larsen 2001), hvor interviewpersonerne opfordres til frit at fortælle historien om deres liv med fokus på deres ægteskab og skilsmisse. Jeg valgte denne tilgang, fordi den egner sig godt til eksplorative studier og dermed synes velvalgt til et emne, hvor den eksisterende litteratur er ganske begrænset. Den åbne, livshistoriske tilgang gør det muligt for informanter selv at lægge vægt på de elementer, de finder relevante (Canger 2008) samt at sammenknytte elementer fra forskellige kontekster, man bevæger sig igennem i løbet af et liv (Gullestad 1996).

Når folk fortæller om begivenheder i deres liv, der i nogle tilfælde foregik for årtier siden, kan metoden også være med til at belyse en historisk udvikling, fx i form af systematiske forskelle i fortællinger om skilsmisser, der fore- 
kom i 1980'erne, sammenlignet med skilsmisser i 2000'erne. Da den enkeltes liv altid er vævet sammen med den større historiske udvikling (Mills 1959), kan en (samtids)historisk og kontekstuel dimension dermed fremanalyseres fra livshistoriske interviews (Wengraf 2000).

I interviewene blev forskellige opfattelser af skilsmisse - nogle med rod i tyrkiske normer, andre knyttet til en dansk kontekst - kontrasteret i livshistorierne, og disse konfigurationer ændrede sig i samklang med den gradvise udvikling i den bagvedliggende større indvandringshistorie. Det var ud fra sådanne observationer, at jeg valgte Arnetts skelnen imellem "snæver" og "bred" socialisation som en relevant analytisk tilgang. Informanternes alder var mellem 24 og 55 år, og de kunne fortælle om skilsmisseerfaringer fra både 1980'erne, 1990'erne og 2000'erne. Ud over førstegenerationsindvandrere og efterkommere var en del informanter også kommet til Danmark i forbindelse med et ægteskab, der siden var gået i stykker. Faktisk viser tallene, at den ene ægtefælle var familiesammenført i hele 92 \% af de tyrkisk-tyrkiske ægteskaber, der blev indgået i perioden fra 1981 til 1999 (og dermed i tiden før stramningerne i de danske familiesammenføringsregler).

Socialt dækker informanterne et bredt spektrum: Især blandt de oprindelige indvandrere og de familiesammenførte ægtefæller fra Tyrkiet er der en overvægt af kortuddannede personer, mens de af informanterne, der er opvokset i Danmark, svinger fra at have ingen, til at have mellemlange og lange kompetencegivende uddannelser. Hovedparten af alle informanternes forældre havde kun en kort skolebaggrund - hyppigt 5 år.

Efter informanternes valg foregik interviewene enten på dansk eller på tyrkisk. Med to undtagelser, der skyldes informanternes ønsker herom, blev alle interviews optaget på bånd og efterfølgende udskrevet. Alle informanter er anonymiseret, og jeg kan have ændret personlige detaljer for at sikre denne anonymitet. Efterfølgende brugte jeg dataprogrammet NVivo til at kode alle interviews i forhold til temaer som migrationsbaggrund, ægteskabets indgåelse, skilsmissens forløb, forældrenes indflydelse på forskellige tidspunkter mv. Til denne artikels analyse udvalgte jeg informanter, der tilsammen både belyser forandringsprocesserne over tid, og som indfanger noget af den store kompleksitet, der er i materialet.

\section{De første indvandrere - skilsmisser var sjældne og stig- matiserende}

Interviewmaterialets tidligste eksempel på en skilsmisse stammer fra Manolya. På et sommerferiebesøg til hendes landsby i 1973 bad en mand, der havde fundet arbejde i Danmark, Manolyas far om hans 18-årige datters hånd, og kort efter blev de to gift. Manolya rejste med sin mand til Danmark, men her erfarede hun, at ægteskabet slet ikke fungerede. Da hun året efter besøgte sin far i Tyrkiet, vovede hun at klage sin nød, og fortalte sin far, at hun gerne ville forlade sin mand: 
Jeg græd, og jeg bad om ikke at skulle rejse tilbage til Danmark. Jeg var meget ulykkelig. Men min far ville ikke have det - det var hans ære, sagde han. Han brugte udtrykket: "Jeg har givet dig en hvid brudekjole - når du kommer tilbage, skal det være i en hvid kiste". Så det var håbløst; jeg kunne ikke gøre noget.

På linje med den "snævre" socialisation, der eksisterede i det landlige Tyrkiet på denne tid, var den eneste ønskelige og forventelige udvikling for en ung kvinde som Manolya at blive gift i det, vi fra dansk side kan synes er en "ung alder". Endvidere var vejen ind i et sådan ægteskab smal og nøje fastlagt: Parret skulle inden ægteskabet ikke have tæt kontakt med hinanden, og forældrenes (især fædrenes) billigelse af ægteskabet var vigtig (Delaney 1991). Manolya fulgte denne fastlagte vej og måtte - da hun umiddelbart efter fortrød giftemålet - sande, at hendes far forventede konformitet i henhold til gældende normer. Dermed var skilsmisse udelukket.

Socialiseret til en høj grad af lydighed, bøjede Manolya sig for sin fars kategoriske tilbagemelding og blev hos sin mand i mere end et årti. Men i Danmark var livsomstændighederne anderledes end i den tyrkiske landsby, hun kom fra. Hun lærte dansk, kom i uddannelse og fik efterfølgende arbejde. Som årene gik, blev hun såvel mere personligt som økonomisk selvstændig, ligesom hun lærte livet i Danmark bedre at kende.

Det førte frem til, at Manolya i 1985 egenhændigt og uden sin fars billigelse valgte at forlade sin mand. Hun fortæller i interviewet:

Jeg var den første [der blev skilt]. Måske var der nogen, jeg ikke kendte, men der var ikke nogen fraskilte i min omgangskreds. Og dem, der tager det første skridt, betaler altid en høj pris.

Den høje pris var blandt andet, at Manolya blev socialt isoleret fra store dele af det tyrkiske immigrantsamfund for at have brudt tidens sociale normer imod skilsmisse og handlet individuelt og dermed afvigende i forhold til de gældende forventninger.

Et andet eksempel på de stærke normer imod skilsmisser, der i mit interviewmateriale ofte kan observeres blandt førstegenerationen, kommer fra en informant, som blev gift omkring 1990. Hun opdagede snart, at svigerforældrene - der var indvandret i 1970'erne - havde et meget dårligt ægteskab, hvor manden var sin kone utro. Svigermoderen led under dette, men uanset at hendes egne voksne børn forsøgte at overtale hende til at blive skilt, ville hun ikke høre tale om det. Eksemplet viser såvel de stærke normer imod skilsmisser blandt de oprindelige indvandrere, som at de store børn, der er opvokset i Danmark, kan se anderledes på tingene. Netop forandringer fra indvandrere til efterkommere i forhold til skilsmisser er temaet for næste afsnit. 


\section{Gradvise forandringer over tid}

Når skilsmisser, som statistikken i figur 1 viser, var forholdsvis sjældne især i starten af 1980'erne, kan det altså forklares ved, at begge parter i tyrkiske ægtepar i Danmark normalt var vokset op med den "snævre" socialisation, man fandt i tyrkiske landsbyer, hvor skilsmisser nærmest var utænkelige, og som - hvis de ind traf - $\mathrm{i}$ høj grad kunne ødelægge især kvinders livschancer.

Denne "snævre" socialisation med fokus på konformitet blev umiddelbart videreført i Danmark. Fx fortæller flere kvinder, der er opvokset i Danmark i 1980'erne, at de fra barnsben lærte, at det var forventeligt og ønskeligt, at en ung kvinde skulle indgå i et ægteskab i en tidlig alder og forblive heri. Omvendt var der på dette tidspunkt ikke den store fokus på uddannelse i tyrkiske familier i Danmark. Således gik cirka halvdelen af de unge tyrkere, der forlod grundskolen omkring 1990, slet ikke videre i uddannelsessystemet (Jakobsen m.fl. 2010:97).

Et eksempel fra denne periode på en opvækst præget af "snæver" socialisation rettet mod et tidligt, varigt ægteskab, kommer fra Dilek. Hun blev født i 1973 i en tyrkisk landsby og kom til Danmark som spæd. Hun droppede ud af 8. klasse, og kort tid efter fik familien et tilbud om ægteskab fra en slægtnings søn, der allerede var bosat i Danmark. Familien (og Dilek) accepterede tilbuddet, og i 1988 blev 16-årige Dilek gift og flyttede ind hos sin mand og sin nye svigerfamilie. Ægteskabet var en muslimsk nikah (Liversage 2012a). De søgte om at få kongebrev til giftemålet, men dette blev afvist, hvorfor parret ikke var gift efter dansk lov. I sit nye hjem udfyldte Dilek rollen som svigerdatter med stort ansvar for det huslige arbejde og indordnede sig under reglerne om, at hun fx ikke måtte forlade lejligheden alene. Det viste sig hurtigt, at Dilek havde svært ved at blive gravid, hvilket var en streg i regningen i forhold til det forventede forløb for et ungt gift par. Hun gik i behandling for barnløshed, hvilket belastede hendes helbred og krævede adskillige hospitalsindlæggelser. Hun oplevede samtidig, at hun og hendes mand ikke havde det godt sammen. Hun fik det værre og værre med sin situation og nåede, da hun var i midten af tyverne til et punkt, hvor hun ønskede at forlade ægteskabet. Hun fortæller følgende herom:

Jeg følte, at nu kunne jeg ikke magte mere. På et tidspunkt, hvor jeg var indlagt på hospitalet, tog jeg beslutningen om, at nu var det slut. Jeg ringede til mine forældre og sagde, de skulle komme og hente mig, for jeg var virkelig langt nede. Jeg håbede, at mine forældre ville bakke mig op. Men min far sagde: "Hvad vil folk ikke sige?" Der var ikke rigtig noget støtte at hente der, og det sidste jeg ville var at såre mine forældre. Så jeg gav [ægteskabet] en chance til. Men når man først har lagt kortene på bordet, så er det rigtig hårdt - så venter der en frygtelig dagligdag [...] Og så var der en masse ældre mennesker, der kom for at prøve at tale mig til fornuft. Sådan er det, når nogen vil skilles. De 
ville have mig til at se det rigtige, fordi "du er sådan sindssyg". Så jeg vendte tilbage [til manden og svigerforældrene] og prøvede at få det til at fungere. Jeg kunne se på ham, at han også prøvede på at ændre sig at være mere sammen med mig.

Ligesom Manolya forlod Dilek altså ikke sin mand, første gang hun åbent udtrykte ønsker herom, fordi hun mødte modstand imod skilsmisse fra blandt andet sin far. Hun blev dog skilt, da hun var omkring 30 år. Her havde parret dels fået et barn, dels var de flyttet bort fra svigerforældrene, og endelig afslørede Dilek sin mand i længerevarende utroskab. Dilek fik efterfølgende sine forældres støtte til sin skilsmisse, men blev isoleret i forhold til dele af det tyrkiske lokalsamfund.

På linje med Manolyas historie illustrerer også Dileks historie vanskelighederne ved at afvige fra det spor, man på det tidspunkt forventedes at følge, og at lydighed over for forældre - der fastholdt en modstand imod skilsmisser kunne være af stor betydning for, hvordan den enkelte handlede. Samtidig viser citatet også, at det tyrkiske "lokalsamfund" i Danmark også har støttet op om modstanden imod individuelle afvigelser fra fastlagte normer - i Dileks tilfælde ved at lokale tyrkiske ældre forsøgte at tale hende bort fra ideen om skilsmisse og dermed "til fornuft". Samtidig er konteksten dog også dansk. Her kunne tyrkiske kvinder som Manolya og Dilek opleve, at fx danske kolleger ikke tog afstand fra deres skilsmisser, men tværtimod støttede dem heri; at skilsmisse juridisk var nemmere tilgængeligt i Danmark, end det ville have været i Tyrkiet, også selvom manden ikke tilsluttede sig ønsket herom (Örücü 2010); og at der i Danmark fx var mulighed for, at en enlig mor kunne arbejde og forsørge sig selv.

\section{Kønsforskelle og deres betydninger for skilsmisser}

Arnett fremhæver (1995), at der inden for de enkelte kulturer naturligvis er variationer i forhold til forskellige individers og gruppers socialisation. En del af denne variation handler om kønsforskelle, hvor "the socialization of girls tends to be narrower than the socialization of boys" (1995:624). Denne forskel går igen i denne undersøgelses materiale. Dette hænger ikke kun sammen med kønsforskelle i tyrkiske forældres socialisation af deres børn, men også med kønsforskelle i unge tyrkiske kvinder og mænds adgang til livet uden for familierne og dermed, i hvilken grad de kan modtage impulser fra det majoritetsdanske samfund. Unge, der - som Dilek - ikke blev en del af det kønsblandede danske uddannelsessystem ud over fx folkeskolen, kunne for kvinders vedkommende tilbringe en ganske stor del af deres tid i hjem, hvor tyrkiske normer herskede. Unge mænd, derimod, ville i højere grad både være i beskæftigelse og have et fritidsliv uden for hjemmets rammer. Med mindre fokus på mænds seksuelle afholdenhed før ægteskabet, kunne unge mænd her også indlede kæresteforhold, fx til piger fra den danske majoritet, der ikke skulle leve op til krav om seksuel afholdenhed før ægteskabet. 
Uanset unge tyrkiske mænds større råderum med hensyn til deres liv i de sene teenageår, ville de dog normalt også møde forventninger om at blive gift i en ung alder, og det med en tyrkisk ægtefælle, som forældrene kunne sige god for. Flere interviews indikerer, at grundlaget for nogle skilsmisser blev lagt, når unge mænd - på deres forældres initiativ - blev gift uden selv at ville det fuldt og helt. Med sameksistensen af forskellige domæner kan sådanne unge mænd nemlig på den ene side vælge at gå med til et ægteskab med en tyrkisk kvinde, der ofte skulle familiesammenføres fra Tyrkiet. På den anden side kan de unge mænd dog undlade at udfylde rollen som "ægtemand". De har i stedet en kønsbetinget mulighed for at fortsætte deres liv i domænerne uden for familien, $\mathrm{fx}$ i arbejds- og nattelivet, og dermed kan et sådan ægteskab bærer kimen til sin egen opløsning i sig fra starten.

Ebru oplevede noget sådant: Hun var opvokset i en tyrkisk landsby og blev som 19-årig gift med sin fætter i Danmark. Også hun flyttede ind til svigerforældrene, hvor manden stadigt boede, men hun oplevede her, at hendes mand sjældent var hjemme. Ebru måtte snart sande, at ægteskabet slet ikke var, som hun havde forestillet sig, det ville være:

Da jeg kom til Danmark troede jeg, at han var lige så parat til at blive gift som jeg var. Men det var han slet ikke. Han var en ung mand, som gik i byen og som havde fuldtidsjob - sådan et 12-timers job på et pizzeria. Han kom hjem sent om natten og havde ikke tid til noget som helst. Jeg prøvede at ændre på det, for det var ligesom ikke det, jeg havde forestillet mig. Jeg opdagede også, at han så andre piger. Så vi diskuterede og skændtes tit. Og så fortalte han mig, at det ikke var ham, der ønskede at blive gift. Det var hans forældre, der sagde at han skulle, og til sidst havde han sagt "ja", fordi de blev ved med at presse ham.

Ebru forsøgte i to år at få sin mand til at ændre adfærd, men uden held. Da hans utroskab blev stadigt mere åbenlys, besluttede Ebru sig til slut for at forlade ham. Modsat Manolya blev Ebru støttet heri af sin far i Tyrkiet.

Uanset at Ebrus svigerforældre altså var i stand til at presse deres søn ind på ægteskabets smalle sti i den normativt foreskrevne unge alder, udspillede meget af sønnens liv sig i domæner, der ikke var underlagt forældrenes og det tyrkiske lokalsamfunds kontrol. Her havde Ebrus mand mulighed for at vælge en anderledes og mere individuel vej mod sit voksne liv end den, hans forældre foreskrev, og dermed var ægteskabet uholdbart fra starten (se også Charsley \& Liversage 2013, Liversage 2009b).

Transnationale ægteskaber, hvor unge mænd på den ene side bøjer sig for forældres ønsker om, at de indgår ægteskab med en hustru, forældrene har valgt, men sideløbende hermed lever et liv i andre og friere rammer, ses også fx blandt pakistanere i England (Charsley \& Liversage 2013). Tilsvarende mener et studie at kunne dokumentere, at en stor del af de transnationale ægte- 
skaber, der indgås i Skotland, er såkaldt "incompatible marriages", der opstår $i$ et spændingsfelt imellem forældres og store børns divergerende syn på ægteskab. En del af disse ægteskaber ender efterfølgende i skilsmisse (Werbner 2007:168). De familiesammenførte ægtefæller, især kvinderne, kan her komme til at stå tilbage som tabere (Liversage, under udgivelse $\mathrm{a}, \mathrm{b}$ ).

\section{Modsatrettede impulser i forhold til ægteskab og skils- misse}

Vurderet ud fra denne undersøgelses interviews er det ikke kun imellem forældre og unge, der kan sameksistere forskelligartede forestillinger om, hvornår og hvordan ægteskaber bør indgås. Også inden $i$ den enkelte unge kan der findes modstridende forestillinger (Bille 2011) - et forståeligt produkt af at være vokset op i en kontekst, hvor såvel "snævre" som "brede" tilgange til socialisation sameksisterer. Et eksempel herpå ses i interviewet med Ayla.

Hun voksede op i Danmark, og hendes forældre havde ingen planer om, at hun skulle giftes tidligt. Dog forventede de, at hun ikke havde kærester, hvilket Ayla også levede op til. Som 19-årig (midt i 1990'erne) tog Ayla med sine forældre på ferie til Tyrkiet. Da hun vidste, at hun her ville møde mange friere, fik hun sine forældre til at love at afvise alle unge mænd på hendes vegne. Det gjorde forældrene, men én familie insisterede på at høre afvisningen fra Aylas egen mund. Hun gik derfor med til at møde den standhaftige frier, hvorefter det følgende skete:

Så snakker jeg med ham, og der sker der et eller andet. Jeg bliver absolut ikke forelsket $\mathrm{i}$ ham, men for første gang sidder man over for en tyrkisk fremmed mand og har en snak. Og på det tidspunkt er jeg 19 år, og jeg føler lidt, at nu har jeg jo talt med ham - at jeg lidt har involveret mig med ham. Og så tænker jeg: "Nå ja, det kan ligeså godt være ham som det kan være en anden - jeg skal jo giftes før eller siden". Jeg har ikke prøvet at være forelsket, så jeg aner ikke hvad det er, jeg skal mærke efter, når jeg nu tænker i ægteskabsbaner. Og så bliver vi gift - efter ni dage, for vi skulle jo nå at gøre det, inden ferien er slut [latter]. Og så vågner jeg op og tænker: "Shit, hvad er det, jeg har rodet mig ud i?"

Aylas forudanelse om, at hun var på vej ind i et dårligt ægteskab, viste sig at holde stik, og hun blev skilt to år senere. Dette skete dog først efter, at hun havde gjort seriøse forsøg på at få forholdet til at fungere: De kønsspecifikke normer og forventninger i forhold til at bevare et indgået ægteskab vejer stadig tungt og er særligt noget, det påhviler kvinder at tage vare på. Dette er dermed endnu et eksempel på et sammenstød imellem en "snæver" og en "bred" socialisation og dermed sameksisterende, men forskelligartede forventninger til, i hvilken grad ens liv skal styres af henholdsvis konformitet (til tyrkiske forventninger) og individualitet. I Aylas tilfælde havde hun dels en 
impuls til at gifte sig på det (tyrkisk) "rigtige" (tidlige) tidspunkt - og uden nærmere kendskab til sin ægtefælle. Da problemerne med dette valg - som i en dansk optik var indgået både uovervejet og i en ung alder - efterfølgende viste sig, var Ayla i stand til at blive skilt og få sin families støtte hertil. Hendes mulighed herfor illustrerer bevægelsen imod en øget accept af skilsmisser og dermed, at ikke alle behøver at følge den samme "snævre" sti i deres familieliv.

\section{Køn, skilsmisser og forandringer i en migrationskontekst}

Som nævnt viser registerdata, at skilsmisser over tid bliver stadig hyppigere blandt tyrkere i Danmark, og dermed fjerner gruppen sig fra de oprindelige forventninger til ægteskabers beståen. Især når det er tyrkiske kvinder, der i Danmark tager initiativ til skilsmisse, kan dette opleves som et brud med den kvindelige lydighed, der både er et centralt element i det "klassiske patriarkat", der har stor betydning især i landområderne i Tyrkiet (Kandiyoti 1988, Kandiyoti 1995, Moghadam 2004), og vigtig i den "snævre socialisations" konformitet. Samtidig tilskrives kvinders seksuelle adfærd generelt stor betydning i etniske minoritetsgrupper (Yuval-Davis 1997), og det, at nogle tyrkiske kvinder i Danmark anvender skilsmisser til individuelt at søge at forbedre deres liv frem for at leve op til normative forventninger, kan ses som en udfordring af eksisterende kønsrelationer og som noget, der styrker kvinder frem for mænd.

Overordnet set har skilsmissefrekvensen i forskellige lande da også en klar sammenhæng med, om kvinder kan klare sig selv økonomisk eller ej (Becker 1981), og den relative styrkelse af kvinderne (i forhold til deres muligheder for at afslutte uønskede ægteskaber) skal derfor ses i den bredere samfundsmæssige kontekst. Centralt her står, at den kvindelig erhvervsfrekvens i Danmark er på $72 \%$, imod blot 25 \% i Tyrkiet (ILO 2008, Danmarks Statistik 2011), ligesom eksistensen af fx sociale ydelser og offentlige dagspasningsinstitutioner i Danmark er af stor betydning. Som ægteskabsmigranten Nilgün formulerer det, var denne danske kontekst væsentlig for, at hun kunne vælge skilsmisse frem for at blive i et dårligt ægteskab:

Danmark er et meget kvindevenligt samfund. Se på mig - enlig mor, og indvandrerkvinde, som ikke er opvokset i Danmark: Jeg fik mulighed for at uddanne mig, og jeg kom ud på arbejdsmarkedet. Ellers havde jeg skulle finde mig i [eksmand] og være ulykkelig. Så jeg takker det danske samfund - det er det eneste, jeg kan sige. Det var det danske samfund, der gav mig et godt liv.

Hvor kvinden Nilgün her føler, at den danske stat gav hende mulighed for at forlade et dårligt ægteskab, kan nogle tyrkiske mænd omvendt opleve, at den danske stat underminerer både deres position og deres ægteskaber (Liversage 2012b, Charsley og Liversage, under review). Dette giver ægteskabsmigran- 
ten Tayfun udtryk for. Han blev gift og familiesammenført til Danmark, da han var 21 år og fik her to børn med sin kone, der var opvokset i Danmark. Hans kone valgte efter ti års ægteskab at uddanne sig inden for social- og sundhedsområdet og ønskede samtidigt hermed skilsmisse. Dette skete uanset, at Tayfun følte, at deres ægteskab var udmærket. Tayfun giver direkte den danske stats støtte til fraskilte kvinder skylden for denne skilsmisse:

Der er alt for mange, der bliver skilt. For de tænker: "Vi kan godt blive skilt, for stat-far (devlet-baba) passer på os". Bare her, i dette [bolig]byggeri, er der måske 10 eller 15, der er fraskilte. Sådan er situationen nu. Og det er meget skadeligt for børnene. Det tog meget hårdt på mine sønner, at vi blev skilt.

Disse to citater indikerer, at det i højere grad er kvinderne frem for mændene, der slutter sig til det synspunkt, at skilsmisser er acceptable. At det - som Nilgün siger - er bedre at blive skilt end at "være ulykkelig". Tayfun fokuserer i stedet på noget, man kan betegne som "sædernes forfald". Her kan mænd, der tidligere havde den overordnede magt og det overordnede ansvar i familierne, blandt andet fordi de var forsørgere (Delaney 1991), opleve, at de mister denne position i takt med en stigende grad af individualisering, hvor $\mathrm{fx}$ kvinder begynder at træffer selvstændige valg, der afviger fra tidligere tiders smalle og slagne sti.

\section{Tyrkiske kvinders øgede uddannelsesniveau som en mulig medvirkende faktor}

Ud over etniske minoritetskvinders deltagelse i det danske arbejdsmarked kan også en stigende uddannelsesfrekvens - og dermed en øget eksponering til socialisation i en dansk skolekontekst - ligge bag stigningen i skilsmisser, forstået som en bevægelse fra en "snæver" hen imod en mere "bred" socialisation. Og her er der virkelig sket en udvikling. Som tidligere nævnt var det i 1990 omkring halvdelen af tyrkiske unge i Danmark, som ikke uddannede sig efter grundskolen. Blot ti år senere gjaldt dette kun for henholdsvis $19 \%$ af de unge tyrkiske mænd og $16 \%$ af de unge tyrkiske kvinder (Jakobsen m.fl. 2010). Med et stigende uddannelsesniveau tilbringer unge tyrkere i Danmark stadig mere tid i uddannelsessystemet, hvilket kan tænkes at fremme ønsker om individuelle valg, fx om en fremtidig karriere på arbejdsmarkedet, frem for konformitet til et snævert spor lig det, der følges i tyrkiske landsbyer.

Socialisation i uddannelsens domæne kan dermed medvirke til, at unge - og i stigende grad veluddannede - mennesker har større ønsker om at forme deres egne liv på egne måder og også bedre ressourcer til at opnå dette (Therborn 2005). Det kan både handle om ikke at gifte sig unge eller - ifald de bliver gift - om at forlade ægteskaber, som de oplever som dårlige. Dette kan naturligvis gælde for unge mænd såvel som for unge kvinder, men 
set i forhold til udgangspunktet i Tyrkiet lader denne proces til i særlig grad at have øget kvindernes muligheder for at handle. Güler, født og opvokset i Danmark, blev i 2009 skilt fra sin ligeledes herboende mand efter et tre-årigt ægteskab. På linje med, at tyrkiske kvinder i dag uddanner sig klart mere end tyrkiske mænd, fik også Güler mere uddannelse end sin mand og fremhæver selv dette som noget, der gav spændinger i ægteskabet og var medvirkende til, at det gik i stykker:

[Ex-mand] kunne slet ikke have, at jeg uddannede mig: Han var ufaglært, og [mente at] kvinden ikke skal være længere fremme end ham. [Hun vrænger, og efterligner en mandestemme:] "Den tyrkiske tradition siger, at konen skal være 100 meter bag manden!" [Med sin egen stemme:] Gu' gør den ej! Det er hans hjerne der siger det!

Det var Güler, der valgte at afslutte ægteskabet (hvilket hun fik sine forældres støtte til). Også mere generelt lader det til at være kvindelige frem for mandlige, tyrkiske efterkommere, der mest overtager den positive danske indstilling til skilsmisse. ${ }^{4}$ Det viser en survey-undersøgelse, udført med ca. 500 tyrkiske indvandrere, 500 tyrkiske efterkommere og 500 etniske danskere (Tænketanken 2007).

Hverken blandt tyrkiske indvandrere (hvor knap $40 \%$ er negative over for skilsmisser) eller blandt majoritetsdanskere (hvor kun ca. $5 \%$ er negative over for skilsmisser) er der nogen særlig kønsforskel. Anderledes er situationen blandt tyrkiske efterkommere: Her er $30 \%$ af de mandlige efterkommere negative og kun 29 \% positive over for skilsmisse. Hos de kvindelige efterkommere derimod, er $17 \%$ negative over for skilsmisser, mens næsten halvdelen - $48 \%$ - er positive over for skilsmisse (Kosar 2011). Modsat situationen hos såvel førstegenerationen af tyrkere som blandt majoritetsdanskerne er der altså en betragtelig kønsforskel i indstillingen til skilsmisse blandt tyrkiske efterkommere. Her er det kvinder frem for mænd, der har taget den positive opfattelse af skilsmisse til sig.

At det er denne udvikling, der finder sted i den tyrkiske indvandrergruppe over tid, kan også ses i sammenhæng med, at den nordiske velfærdsstat i høj grad har været et "kvindevenligt" projekt, der på mange måder har øget kvinders individuelle autonomi (Borchorst \& Siim 2008, Hernes 1987). Hvor tyrkiske fraskilte kvinder dermed kan have relativt gode muligheder i Danmark (når sammenligningsgrundlaget er situationen i Tyrkiet), viser anden forskning modsat, at etniske minoritetsmænd i nogle tilfælde kan stå svagt efter en skilsmisse. Således mister de hyppigere helt kontakten med deres børn efter skilsmissen, end majoritetsdanske fraskilte mænd gør (Liversage, forthcoming b), ligesom skilsmisse for nogle mænd fører til hjemløshed (Järvinen 2004, Charsley og Liversage, under review). 


\section{Konklusion}

Registerdataanalyserne i denne artikel viser, at der fra starten af 1980erne og frem mod i dag er sket en stigning i andelen af tyrkiske ægteskaber i Danmark, der ender i skilsmisse. Skilsmisseniveauet i gruppen er således steget fra det lave niveau, der findes i Tyrkiet, til nu at tangere det klart højere danske skilsmisseniveau.

Med afsæt i Arnetts (1995) begreber om socialisation, argumenterer jeg for, at nogle af årsagerne til denne stigning kan findes i en gradvis - og konfliktfyldt - bevægelse fra en "snæver" til en "bredere" socialisation over tid. I starten af 1980'erne havde de få tyrkiske par, der blev skilt i Danmark, således normalt begge haft hovedparten af deres opvækst i Tyrkiet og havde dermed ikke været under så stor indflydelse fra de normer og praksisser, der er gældende i den danske kontekst, ligesom de heller ikke havde haft gavn af $\mathrm{fx}$ de ressourcer, man kan tilegne sig i det danske uddannelsessystem. I de efterfølgende år stiger indflydelsen fra den danske kontekst dog for de unge mennesker, der vokser op i Danmark. De eksponeres her til en forskelligartet socialisation - på den ene side står familien og eventuelt et tyrkisk-domineret lokalmiljø, og på den anden side det danske uddannelses-, arbejds- og fritidsliv.

Dermed kan der opstå spændinger imellem forældre og deres store børn: Her kan forældre ønske en "snæver" socialisation af deres børn - og lægge vægt på en konformitet, der blandt andet indebærer, at man gifter sig med bestemte ægtefæller i en ung alder, og at man ikke bliver skilt. Heroverfor står børnene, som i højere grad er præget af det danske majoritetssamfunds fokus på individuel selvstændighed og personlige valg, og at skilsmisse klart er at foretrække frem for et dårligt ægteskab. Ud over forløbene af skilsmisserne som sådan, kan også processerne omkring ægteskabers indgåelse være præget af spændinger imellem fx forældre og deres store børn i forhold til, hvorledes familier bør stiftes. Her illustrerer interviewene, at nogle af de ægteskaber, der er blevet indgået i Danmark har været af en sådan karakter, at de i længden ikke har kunnet holde i et dansk samfund, hvor der fx ikke er større materielle hindringer for, at fraskilte kvinder kan klare sig økonomisk.

Endelig forskydes modstillingen over tid, og vægten flyttes gradvist fra en klart "snæver/tyrkisk", mod en mere "bred/dansk" forståelse af skilsmisser. Denne gradvise og modsætningsfyldte forskydning kan være med til at forklare nogle af de konflikter og modsætninger, som er fremgået af denne undersøgelses kvalitative materiale, såvel som den vækst i skilsmisseraten over tid, som dokumenteres af undersøgelsens kvantitative resultater. 


\section{Noter}

1. Af specialer på området kan nævnes Jesuloganathan 2010, Koudal 2008, Zomorodi 2007.

2. Artiklens emne er skilsmisser blandt indvandrere og efterkommere med baggrund i Tyrkiet. Her benyttes Danmarks statistiks afgrænsning, ifølge hvilken indvandrere er født i udlandet, mens efterkommere er født i Danmark, men har forældre der begge er født i udlandet (Danmarks Statistik 2011). Af sproglige hensyn betegnes hele denne gruppe efterfølgende som "tyrkere". Denne gruppebetegnelse inkluderer dermed dels efterkommere, født og opvokset i Danmark (hvis forældre har rødder i Tyrkiet), og dels personer der fx kunne betegnes som "kurdere" frem for "tyrkere".

3. Der er visse usikkerheder i disse data. Fx står enkelte ægtepar opgjort med to forskellige årstal for ægteskabets indgåelse (fx at manden står opført som gift i 1985, mens hans hustru står opført som gift i 1987). Sådanne unøjagtigheder kan muligvis stamme fra fejl opstået under indvandrede ægtepars registrering hos de danske myndigheder. De burde dog ikke have større indflydelse på det samlede datagrundlag. Det skal også tilføjes, at den sidste tidsserie (ægteskaber indgået 20002003) er kortere end de to foregående serier, og at der forekommer færre skilsmisser her (der er tilsammen 155 skilsmisser inden for disse ægteskabers første fire år, hvor der blandt ægteskaber indgået fra 1990 til 1999 forekommer 430 skilsmisser de første fire år). I mindre datagrundlag får tilfældige udsving større betydning. Dette kan ligge bag serie 3's større uregelmæssighed.

4. En undtagelse fra tyrkiske kvinders generelt forbedrede adgang til skilsmisse i Danmark drejer sig om familiesammenførte kvinder, der ikke har opnået egen, selvstændig opholdstilladelse, og som derfor risikerer at blive udvist af Danmark, hvis de bliver skilt. For en uddybning af denne problematik, se Liversage, under udgivelse a.

\section{Litteratur}

Akpinar, A. 2003: “The Honour/Shame Complex Revisited: Violence Against Women in the Migration Context". Women's Studies International Forum, 26, 5.

Arnett, J. J. 1995: "Broad and Narrow Socialization: The Family in the Context of a Cultural Theory". Journal of Marriage and the Family, 57, 3, 1995:617-628.

Arnett, J. J. 2004: Emerging adulthood: The winding road from the late teens through the twenties. Oxford: Oxford University Press.

Aykan, H. \& D. A. Wolf 2002: “Traditionality, modernity, and household composition: parent-child coresidence in contemporary Turkey". Research on Aging, 22, 4, 2002 : 395-421.

Bille, R. 2011: Den meningsfulde jomfruelighed. Seksualitetens betydning i dannelsen af subjektivitet blandt etniske minoritetspiger i Danmark. Speciale. København, Institut for Antropologi, Københavns Universitet.

Borchorst, A. \& B. Siim 2008: "Woman-friendly policies and state feminism: Theorizing Scandinavian". Feminist Theory, 9, 2, 2008:207-224

Bredal, A. 2006: Vi er jo en familie. Arrangerte ekteskap, autonomi og felleskap blant unge norsk-asiater. Oslo: Unipax.

Canger, T. 2008: Mellem minoritet og majoritet - et ikke-sted. Roskilde: Samfundslitteratur.

Charsley, K. \& A. Liversage 2013: "Transforming polygamy: migration, transnationalism and multiple marriages among Muslim minorities". Global Networks, 13, 1, 2013:60-78.

Charsley, K. \& A. Liversage under review: "Silenced Husbands: Muslim marriage migration and masculinity". 
Cindoglu, D. 1997: “Virginity tests and artificial virginity in modern Turkish medicine". Women's Studies International Forum, 20, 2.

Danmarks Statistik 2011: Indvandrere i Danmark 2011. København: Danmarks Statistik.

Danmarks Statistik 2012: Statistikbanken - www.dst.dk.

Danneskiold-Samsøe, S.; Y. Mørck \& B. W. Sørensen 2011: "Familien betyder alt". Vold mod kvinder i etniske minoritetsfamilier. København: Forlaget Frydenlund.

Darvishpour, M. 1999: "Intensified gender conflicts within Iranian families in Sweden". Nora: Nordic Journal of Women's Studies, 7, 1, 1999:20-33.

Delaney, C. 1991: The Seed and the Soil - Gender and Cosmology in Turkish Village Society. Berkeley: University of California Press.

Gullestad, M. 1996: Everyday Life Philosophers - Modernity, Morality, and Autobiography in Norway. Oslo: Scandinavian University Press.

Guru, S. 2009: "Divorce: obstacles and opportunities - South Asian women in Britain". The Sociological Review, 57, 2, 2009:285-305.

Halman, L.; I. Sieben \& M.v. Zundert 2012: Atlas of European values - Trends and traditions at the turn of the century. Leiden: Brill.

Hart, K. 2007: "Love by arrangement: the ambiguity of "spousal choice" in a Turkish village". Journal of the Royal Anthropological Institute, 13, 2007:345-362.

Hernes, H. 1987: “Women and the Welfare State: The Transition from Private to Public Dependence", i A. S. Sassoon (red.): Women and the State. London: Hutchinson.

ILO 2008: "LABORISTA - database of labour statistics" - http://laborsta.ilo.org.

Jakobsen, V. \& M. Deding 2006: Indvandreres arbejdsliv og familieliv. København: Socialforskningsinstituttet.

Jakobsen, V. \& A. Liversage 2010: Køn og etnicitet i uddannelsessystemet - Litteraturstudier og registerdata . Copenhagen: SFI - the Danish National Centre for Social Research.

Järvinen, M. 2004: Hjemløse flygtninge og indvandrere. København: Hans Reitzels Forlag.

Jesuloganathan, T. M. 2010: "Hellere gift 30 gange end at leve i et ulykkeligt æoteskab" - Et kvalitativt studie af en skilsmisses betydning for forstegeneration somaliske kvinder i Danmark. Speciale. Aalborg: Aalborg Universitet.

Kandiyoti, D. 1988: "Bargaining with patriarchy". Gender and Society, 2, 3, 1988:274-290.

Kandiyoti, D. 1995: "Patterns of patriarchy: notes for an analysis of male dominance in Turkish society", i S. Tekeli (red.):Women in modern Turkish society: a reader. London: Zed Books, 306-318.

Kavas, S. 2010: Post divorce experiences of highly educated and professional women. Ankara: The Graduate School of Social Sciences of Middle East Technical University.

Kosar, A. 2011: "Hvad ville folk ikke sige?" - Skilsmisser blandt etnisk tyrkiske kvinder. Aalborg: 9. semester opgave, Sociologi, Aalborg Universitet.

Koudal, M. 2008: "Of all the lawful acts the most detestable to Allah is divorce" - en kvalitativ analyse af muslimske koinders ret til skilsmisse i krydsfeltet imellem islamisk ret og den danske familieret. København: Speciale, Institut for Tværkulturelle og Regionale Studier, Københavns Universitet.

Liversage, A. (under udgivelse a): "Med loven i hånd: køn, magt og opholdstilladelser i skilsmisser blandt tyrkere i Danmark" i A. Liversage \& M. Rytter (red.): Ægteskab og Migration: Konsekvenser af de danske familiesammenføringsregler 2002-2012. København: Aarhus Universitetsforlag. 
Liversage, A. (under udgivelse b): “Ethnic minority men and fatherhood - examples from Denmark", i T. Rostgaard og G. Eydal: Nordic fatherhoods - Policies, Practices and Discourses of Contemporary Fatherhood. London: Policy Press.

Liversage, A. 2012a: "Muslim divorces in Denmark - finds from an empirical investigation", i R. Mehdi, W. Mensk og J. S. Nielsen (red): Interpreting divorce law in Islam. Copenhagen: DJØF Publishers.

Liversage, A. 2012b: "Gender, conflict and subordination within the household - Turkish migrant marriage and divorce in Denmark". Journal of Ethnic and Migration Studies, 38, 7, 2012:1119-1136.

Liversage, A. 2009a: “Vital conjunctures, shifting horizons: high-skilled female immigrants looking for work". Work, Employment and Society, 23, 1, 2009:120-141.

Liversage, A. 2009b: "Life below a "Language Threshold"? Stories of Turkish Marriage Migrant Women in Denmark". European Journal of Women's Studies, 16, 3, 2009:229248.

Liversage, A. \& T. G. Jensen 2011: Parallelle retsopfattelser i Danmark - et kvalitativt studie af privatretlige praksisser blandt etniske minoriteter. Copenhagen: SFI - the National Centre for Social Welfare.

Mehdi, R. 2007: Integration og retsudvikling. Copenhagen: Jurist- og Økonomforbundets Forlag.

Mehdi, R.; H. Petersen; E.R. Sand \& G.R. Woodman 2008: Law and religion in multicultural societies. Copenhagen: DJØF Publishing Copenhagen.

Mills, C. W. 1959: The Sociological Imagination. Oxford: Oxford University Press.

Moghadam, V. M. 2004: "Patriarchy in transition: Women and the changing family in the Middle East". Journal of Comparative Family Studies, 42, 2, 2004:137-162.

Mooney, N. 2006: "Aspiration, reunification and gender transformation in Jat Sikh marriages from India to Canada". Global Networks, 6, 4, 2006:389-403.

Müftüler-bac, M. 1999: “Turkish Women's Predicament”. Women's Studies International Forum, 22, 3.

Nauck, B. \& D. Klaus 2005: “Families in Turkey”, i: B. N. Adams \& J. Trost (red.): Handbook of World Families. London: Sage Publications, 364-388.

Olsen, A. L.; D. Larsen \& A. Lange 2005: Vielser og Skilsmisser: Børn i Skilsmisser. København: Danmarks Statistik.

Örücü, E. 2010: “Developments in Turkish Family Law”, i: A. Singer, M. Jäntera-Jarenborg, \& A. Schlytter (red.): Familj - religion - rätt. En antologi om kulturella spänningar i familjen - med Sverige och Turkiet som exempel. Uppsala: Iustus.

Ottosen, M. H. 2011: “Familien”, i: H. Andersen et al. (red.): Sociologi-en introduktion. København: Hans Reitzels Forlag, 181-196.

Ozyegin, G. 2009: "Virginal facades: Sexual freedom and guilt among young Turkish women". European Journal of Women's Studies, 16, 2, 2009:103-123.

Rytter, M. 2006: “Ægteskabelig integration: pakistanske og danske arrangerede ægteskaber", i: M. Holm Pedersen \& M. Rytter (red.): Den stille integration: Nye fortællinger om at høre til i Danmark. Copenhagen: C.A. Reitzel, 18-43.

Singla, R. 2006: "Intimate Partnership Formation and Intergenerational Relationships among Ethnic Minority Youth in Denmark". Outlines - critical practice studies, 8, 2, 2006:76-97.

Social- og Integrationsministeriet 2012: Fakta om integration - Status og udvikling. København: Social- og Integrationsministeriet. 
Tænketanken 2007: Værdier og normer - blandt udlændinge og danskere. Copenhagen: Tænketanken for udfordringer om integrationen i Danmark; Ministeriet for Flygtninge, Indvandrere og Integration.

Therborn, G. 2005: "Magt og seksualitet - familien i det 20. århundredes verden". Dansk Sociologi, 16, 1, 2005:127-158.

Timmerman, C. 2008: "Marriage in a "Culture of Migration". Emirdag Marrying into Flanders". European Review, 16, 4, 2008:585-594.

Wengraf, T. 2000: “Uncovering the general from within the particular: From contingencies to typologies in the understanding of cases", i: P. Chamberlayne, J. Bornat, \& T. Wengraf (red.): The turn to biographical methods in social science. London: Routledge.

Werbner, P. 2007: “Veiled Interventions in Pure Space". Theory, Culture and Society, 24, 2, 2007:161-186.

White, J. B. 2004: Money makes us relatives - women's labor in urban Turkey, 2nd edition. London: Routledge.

Yuval-Davis, N. 1997: Gender and Nation. London: Sage.

Zomorodi, P. 2007: "Til kulturen skiller oss ad" - En studie av skilsmisse blandt pakistanske kvinner i Norge. Bergen: Speciale, Institutt for sosialantropologi, Universitetet i Bergen. 